\title{
Separation of Strontium-90 and Yttrium-90 by the Thin-layer Chromatographic Method
}

\author{
Hiroshi Hamaguchi*, Nagao Ikeda, Aiko Imasa** \\ Department of Chemistry, Tokyo Kyoiku University, Otsuka, Tokyo \\ Received June 7, 1964
}

\begin{abstract}
The thin-layer chromatographic method was investigated for the carrier-free separation of ${ }^{90} \mathrm{Sr}$ and ${ }^{90} \mathrm{Y}$ with the several kinds of adsorbents and developers. With the "Wakogel B-0" layer (the silicagel with no binder), ${ }^{90} \mathrm{Sr}$ is transferred farther than ${ }^{90} \mathrm{Y}$ by developing with ethylalcohol-10\% ammonium thiocyanate (5 vol : 3 vol) or ethylalcohol-7M lithium nitrate $(1: 1)$. With the "Wakogel B-5" layer (the silicagel with $5 \%$ plaster of Paris), no separation of these nuclides was attained. With the Dowex 50 resin layer, ${ }^{90} \mathrm{Y}$ is transferred farther with $5 \%$ ammonium citrate solution of $\mathrm{pH} 3.8$. The method has the advantage that one can prepare carrier-free ${ }^{90} \mathrm{Y}$ in a simple way and in a short while.
\end{abstract}

\section{Introduction}

The carrier-free separation of ${ }^{90} \mathrm{Y}$ from the ${ }^{90} \mathrm{Sr}-{ }^{90} \mathrm{Y}$ solution can be attained in various ways: Besides the well-known coprecipitation method and the radiocolloid formation method, several workers reported the successful separation of ${ }^{90} \mathrm{Y}$ by the paper chromatographic method $^{1) \sim 4)}$, ion exchange method using the cationor anion-exchange resin ${ }^{5), 6)}$, ion exchange resin impregnated paper ${ }^{7}$ ) or ion-exchange membrane 8) as well as by the electrolytic method $^{9)}$.

Since the thin-layer chromatographic method was applied to the separation and identification of inorganic ions by Seiler and others ${ }^{10) \sim 14)}$, many papers have already been published with respect to the separation of the various kinds of ions. On the other hand, the application of this technique to the carrier-free separation of radioisotopes is still remained very few. In this paper, the authors tried the thin-layer chromatographic separation of ${ }^{90} \mathrm{Sr}$ and ${ }^{90} \mathrm{Y}$ with the several kinds of adsorbents and developers, showing that this method is useful for the simple and rapid separation of these radioisotopes.

\section{Experimental}

\section{Sample}

${ }^{90} \mathrm{Sr}-{ }^{90} \mathrm{Y}$ used in this experiment was supplied from Oak Ridge National Laboratory (USA). It is diluted in $0.01 N$ hydrochloric acid. One milliliter of the sample solution corresponds to about $5 \mu \mathrm{c}{ }^{90} \mathrm{Sr}+{ }^{90} \mathrm{Y}$. The radiochemical purity was checked in advance.

2. Adsorbents and developers

Adsorbents and developers tried in this experiment are listed in the first and second columns in Table 1.

3. Apparatus

The thin-layer plate of each adsorbent was prepared by the aid of the applicator assembly supplied by CAMAG Chemie-Erzeugnisse und Adsorptionstechnik AG (Switzerland).

4. Procedures

The adsorbent was spread on a $10 \mathrm{~cm} \times 20 \mathrm{~cm}$ glass plate in $300 \mu$ thickness with the applicator. The plate of ion-exchange resin was dried in the air, and that of silicagel was dried in an oven at $110^{\circ} \mathrm{C}$ for 1 hour.

One drop (about $1 \mu l$ ) of the sample solution was mounted on the plate at the point $2.5 \mathrm{~cm}$ from the bottom side with a glass capillary, and dried in the air. The spot was then developed with the various kinds of developers by the ascending method in a closed developing vessel up to about $10 \mathrm{~cm}$ distance.

After the development, the layer was dried

* Present address:

Department of Chemistry, The University of Tokyo, Hongo, Tokyo.

** Present address:

Tokyo Women's Medical College, Ichigayakawada-cho, Tokyo. 
and each $0.5 \mathrm{~cm}$ or $1 \mathrm{~cm}$ section was scraped off and collected in a counting dish. Its radioactivity was then measured by a Geiger-Müller counter.

The distribution of radioactivity on the plate was also investigated by the autoradiographic method: The plate was wrapped with a thin polyvinylidene chloride foil, and laid on a nonscreen type X-ray film. After about 5-10 minutes' exposure, the film was developed.

\section{Results and Discussion}

The results obtained with the various adsorbents and developers are summarized in Table 1. Developing time is the time necessary for $10 \mathrm{~cm}$ developing. It depends upon the kind of the adsorbent and the developer, thickness of the layer and upon the temperature. The Rfvalues for the definite adsorbent and the developer are also slightly influenced by the layer thickness and temperature.

In Figs. 1 3, some examples of the distribution of radioactivity on the layer are shown in the histograms as well as in the autoradiographic pictures. The radioactivity of each fraction was measured after a lapse of $30 \mathrm{~min}$. from the end of development and also after about 90 hours' standing. The radioactivity of ${ }^{90} \mathrm{Y}$ fraction decreases with time, while that of the ${ }^{90} \mathrm{Sr}$ fraction increases owing to the growth of ${ }^{90} \mathrm{Y}$ in it. In this way, the identification of each peak can be readily achieved. The halflife of the decreasing activity was found in good agreement with that of ${ }^{90} \mathrm{Y}(64.2 \mathrm{~h})$. Each autoradiogram shown in the figures was taken after $30 \mathrm{~min}$. from the end of separation.

As is shown in Table 1, when the silicagel layer is used, ${ }^{90} \mathrm{Sr}$ moves farther with the various developers tested, while ${ }^{90} \mathrm{Y}$ is retained near the original point. In the case of the

Table 1 Rf-values for ${ }^{90} \mathrm{Sr}$ and ${ }^{90} \mathrm{Y}$

(Layer thickness: $300 \mu$, Developing distance: $10 \mathrm{~cm}$ )

\begin{tabular}{|c|c|c|c|c|}
\hline Adsorbent & Developer & $\underset{\left({ }^{\circ} \mathrm{C}\right)}{\mathrm{Temp}}$ & $\begin{array}{c}\text { Time } \\
\text { required } \\
\text { (min) }\end{array}$ & $\begin{array}{l}\mathrm{Rf}-\text { values } \\
{ }^{90} \mathrm{Sr}\end{array}{ }^{90} \mathrm{Y}$ \\
\hline Wakogel B-0 & Ethylalcohol-0.5 M HCl (9:1) & 12 & 56 & no separation \\
\hline Wakogel B-0 & Ethylalcohol-2 $M \mathrm{CH}_{3} \mathrm{COOH}(8: 2)$ & 12 & 40 & no separation \\
\hline Wakogel B-0 & Ethylalcohol-0.01 $M$ EDTA $(5: 3)$ & 13 & 30 & no separation \\
\hline Wakogel B-0 & Ethylalcohol-10\% $\mathrm{NH}_{4} \mathrm{CNS}(5: 3)$ & 8 & 92 & 0.07 \\
\hline Wakogel B-0 & Ethylalcohol-7 $M \mathrm{LiNO}_{3}(1: 1)$ & 12 & 46 & 0.12 \\
\hline Wakogel B-0 $+5 \%$ starch & Ethylalcohol-10\% $\mathrm{NH}_{4} \mathrm{CNS}(5: 3)$ & 17 & 45 & 0.05 \\
\hline Wakogel B-0 $+5 \%$ starch & Ethylalcohol-7 $M \mathrm{LiNO}_{3}(1: 1)$ & 13 & 120 & 0.17 \\
\hline $\begin{array}{l}\text { Dowex } 1-\mathrm{X} 8(\mathrm{RCl} \text { form })+5 \% \\
\text { Wakogel B-0 }\end{array}$ & $7 M \mathrm{LiNO}_{3}$ & 20 & 13 & poor separation \\
\hline $\begin{array}{l}\text { Dowex } 1-\mathrm{X} 8\left(\mathrm{NH}_{4} \mathrm{R} \text { form }\right)+5 \% \\
\text { strach }\end{array}$ & $5 \%$ ammonium citrate $(\mathrm{pH}=3.8)$ & 15 & 12 & no separation \\
\hline $\begin{array}{l}\text { Dowex } 50-\mathrm{X} 8\left(\mathrm{NH}_{4} \mathrm{R} \text { form }\right) \\
+20 \% \text { starch }\end{array}$ & $5 \%$ ammonium citrate $(\mathrm{pH}=3.8)$ & 10 & 35 & 0.93 \\
\hline
\end{tabular}

* "Wakogel B-0" is the thin-layer chromatographic silicagel with no binder supplied by Wakō Pure Chemical Industries, Ltd., Tokyo. 


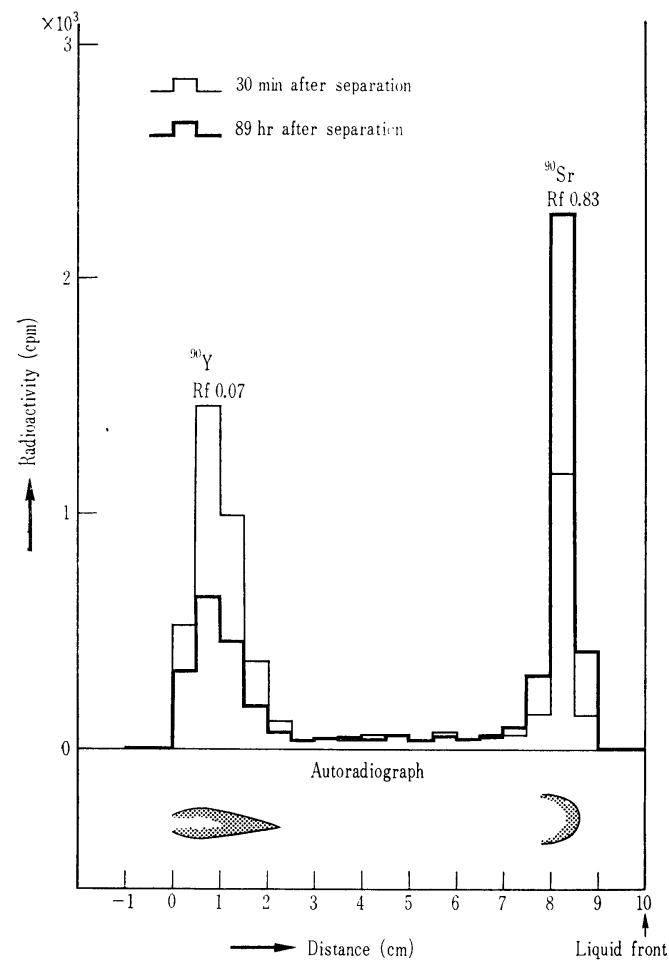

Fig. 1 Distribution of ${ }^{90} \mathrm{Sr}-$ and ${ }^{90} \mathrm{Y}$-activities on the thin-layer chromatographic plate with the corresponding autoradiographic picture.

Layer: Wakogel B-0, $300 \mu$ thickness

Developer: Ethylalcohol-10\% $\mathrm{NH}_{4} \mathrm{CNS}$ $(5: 3)$

Temperature: $8^{\circ} \mathrm{C}$

Autoradiographic detection:

Film: Sakura X-ray film, Industrial type $N$ (high speed, non-screen type)

Exposure: $10 \mathrm{~min}$.

Dowex 50 ion-exchange resin layer, however, the situation is reversed and ${ }^{90} \mathrm{Y}$ is developed farther with $5 \%$ ammonium citrate solution (pH 3.8), just in the same way as in the case of ion-exchanger column chromatography. Ion exchange separation of ${ }^{90} \mathrm{Y}$ on the thin-layer chromatographic plate has the advantage that one can readily prepare citrate-free ${ }^{90} \mathrm{Y}$ in a short while as compared with the column method.

Besides the adsorbents listed in the Table 1, "Alumina B-0"* and "Wakogel B-5"** were also tested, but both ${ }^{90} \mathrm{Sr}$ and ${ }^{90} \mathrm{Y}$ were retained at the original point and no separation was attained. It is probable that the presence of

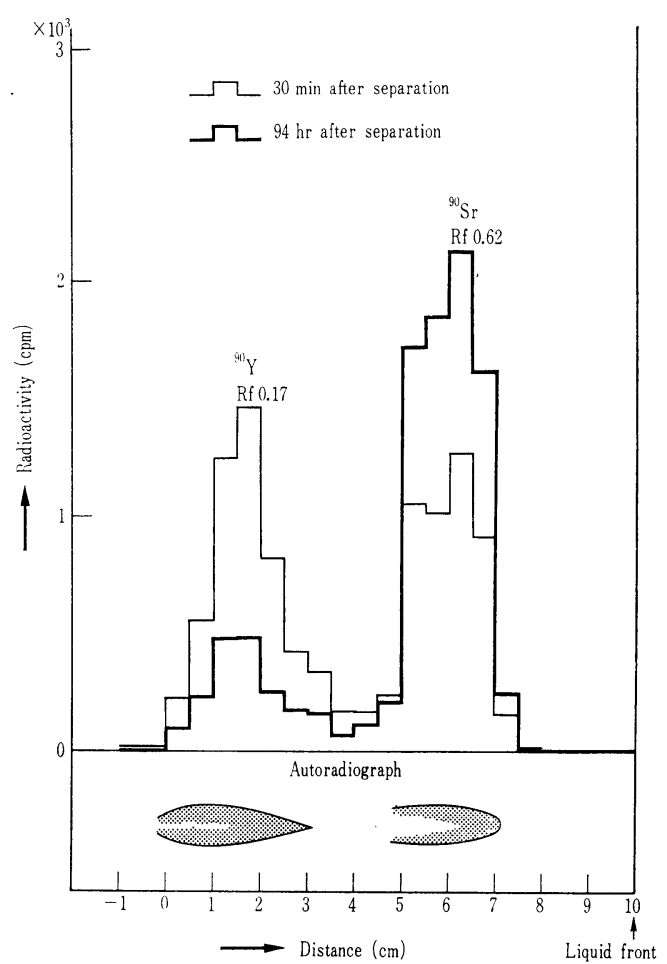

Fig. 2 Distribution of ${ }^{90} \mathrm{Sr}-$ and ${ }^{90} \mathrm{Y}$-activities on the thin-layer chromatographic plate with the corresponding autoradiographic picture.

Layer: Wakogel B-0+5\% starch, $300 \mu$ thickness

Developer: Ethylalcohol-7 $\mathrm{M} \mathrm{LiNO}_{3}$ $(1: 1)$

Temperature: $12^{\circ} \mathrm{C}$

Autoradiographic detection:

Film: Sakura X-ray film, Industrial type $N$ (high speed, non-screen type)

Exposure: $10 \mathrm{~min}$

$5 \%$ calcium sulfate in silicagel hinders the travelling of the carrier-free ${ }^{90} \mathrm{Sr}$ forming the slightly soluble sulfate.

\section{Summary}

The carrier-free separation of ${ }^{90} \mathrm{Sr}$ and ${ }^{90} \mathrm{Y}$ from each other by the thin-layer chromatographic method was investigated. The results

* "Alumina B-0" is the chromatographic alumina with no binder supplied by Wako Pure Chemical Industries, Ltd., Tokyo.

** "Wakogel B-5" is the thin-layer chromatographic silicagel with $5 \%$ calcium sulfate binder supplied by Wakō Pure Chemical Industries, Ltd., Tokyo. 


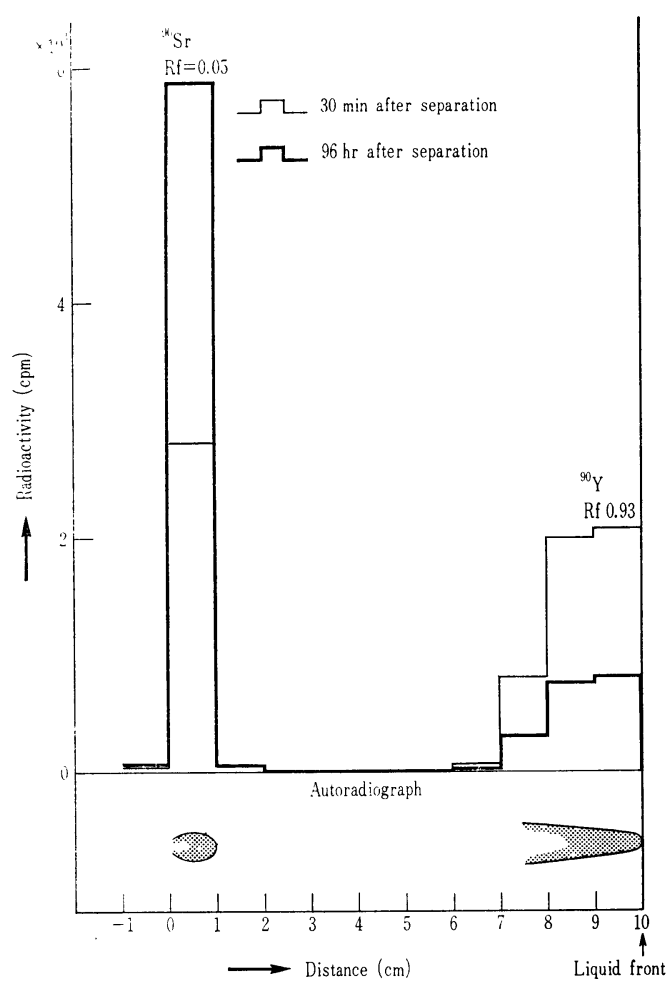

Fig. 3 Distribution of ${ }^{90} \mathrm{Sr}-$ and ${ }^{90} \mathrm{Y}$-activities on the thin-layer chromatographic plate with the corresponding autoradiographic picture.

Layer: Dowex-50 X 8 $\left(\mathrm{NH}_{4} \mathrm{R}\right.$-form, 200-400 mesh) $+20 \%$ starch, $300 \mu$ thickness

Developer: $5 \%$ ammonium citrate $(\mathrm{pH}$ 3. 8)

Temperature: $10^{\circ} \mathrm{C}$

Autoradiographic detection:

Film: Sakura X-ray film, Industrial type $\mathrm{N}$ (high speed, non-screen type)

Exposure: $10 \mathrm{~min}$.

obtained are summarized as follows:

(1) With the silicagel layer, the development with ethylalcohol-10\% ammonium thiocyanate (5 vol:3 vol) or ethylalcohol-7 $M$ lithium nitrate $(1: 1)$ gives a fairly good separation of ${ }^{90} \mathrm{Sr}$ and ${ }^{90} \mathrm{Y}$. In these cases, ${ }^{90} \mathrm{Sr}$ travels farther, while ${ }^{90} \mathrm{Y}$ remains near the original point.

(2) The presence of the calcium sulfate binder in the silicagel hinders the separation, retaining the both nuclides near the original position.

(3) With the cation-exchange resin layer, ${ }^{90} \mathrm{Y}$ is developed farther with $5 \%$ ammonium citrate solution of $\mathrm{pH} 3.8$.

The method is suitable for the simple and rapid separation of ${ }^{90} \mathrm{Sr}$ and ${ }^{90} \mathrm{Y}$.

A part of the expense for this work was defrayed by a grant from the Ministry of Education, to which the authors' thanks are due.

\section{References}

1) T. Kiba, S. Ohashi, T. Minabe: Bull. Chem. Soc. Japan, 29, 745 (1955)

2) M. Leaderer: Anal. Chim. Acta, 15, 122 (1956)

3) H. Gött, D. Pätze: Z. Elektrochem., 58, 636 (1954)

4) N. Matsuura: Japan Analyst, 4, 242 (1955)

5) H. L. Finston, M. John: Ann. Rev. Nucl. Sci., 5, 274 (1955)

6) S. Misumi, T. Taketatsu: J. Inorg. Nucl. Chem., 20, 127 (1961)

7) D. C. Stein: Anal. Chem., 34, 352 (1962)

8) H. Gotō, S. Suzuki, S. Saitō: J.Chem. Soc. Japan (Pure Chem. Section), 81, 60 (1960)

9) H. Hamaguchi, N. Ikeda, T. Kawashima: Japan Analyst, 7, 243 (1958)

10) H. \& M. Seiler: Helv. Chim. Acta, 43, 1939 (1960); 44, 939 (1961)

11) H. Seiler, W. Rothweiler: ibid., 44, 941 (1961)

12) H. Seiler, T. Kaffenberger: ibid., 44, 1282 (1961)

13) H. Seiler: ibid., 44, 1753 (1961); 45, 381 (1962); 46, 2629 (1963)

14) H. Seiler, Chr. Biebricher, H. Erlenmeyer: Helv. Chim. Acta, 46, 2636 (1963) 
要 旨

薄層クロマトグラフ法によるストロンチウム-90よイットリウム-90の分雑

浜口 博, 池田長生, 岩佐露子

東京教育大学

薄層クロマトグラフ法を用いて, ${ }^{90} \mathrm{Sr} か ら{ }^{90} \mathrm{Y}$ を無担体に分離することを試みた。吸着剤として Wakogel B-0 (結着剂を含まないシリカゲル) の薄層を用いるとき，エチルアルコールー10\%チオ シアン酸アンモニウム ( 5 容 : 3 容)，またはエチルアルコールー $7 M$ 硝酸リチウム $(1: 1)$ の展開 溶媒で, ${ }^{90} \mathrm{Sr}$ のほ 5 が ${ }^{90} \mathrm{Y}$ より移動距離が大きい。しかし Wakogel B-5（5\%の石高を含むシリ カゲル）を使用するときは，分離できず，どちらも原点付近にとどまる。また陽イオン交換樹脂 (Dowex 50) で薄層を作り，5\%クエン酸アンモニウム溶液（pH=3.8）で展開するときは, ${ }^{90} \mathrm{Sr}$ 原点にとどまり， ${ }^{90} \mathrm{Y}$ が展開先端へ移動する。本法により， ${ }^{90} \mathrm{Y}$ を簡単，迅速に無担体に分離する ことができる。 